Supporting Information

\title{
Unexpected Function of a Heptapeptide-Conjugated Zwitterionic Polymer that Coassembles into $\beta$-Amyloid Fibrils and Eliminates the Amyloid Cytotoxicity
}

Wenjuan Wang, ${ }^{\dagger, \xi}$ Guangfu Zhao, ${ }^{\dagger, \xi}$ Xiaoyan Dong, ${ }^{\dagger, t}$ and Yan Sun ${ }^{*,+, \neq}$

$\dagger$ Department of Biochemical Engineering, School of Chemical Engineering and Technology, Tianjin University, Tianjin 300350, China.

\$ Key Laboratory of Systems Bioengineering and Frontiers Science Center for Synthetic Biology (Ministry of Education), Tianjin University, Tianjin 300350, China.

*Corresponding Author: Yan Sun

E-mail: ysun@tju.edu.cn. 


\section{Additional Experimental Details}

Preparation of $\mathbf{A} \boldsymbol{\beta}$ Monomer Solution. The lyophilized $A \beta\left(A \beta_{40}\right.$ or $\left.A \beta_{42}\right)$ protein was dissolved in HFIP to $1.0 \mathrm{mg} / \mathrm{mL}$ and kept in quiescence for at least $2 \mathrm{~h}$, then the solution was sonicated for $30 \mathrm{~min}$ in an ice bath and centrifuged at $16000 \mathrm{~g}$ for $30 \mathrm{~min}$ at $4{ }^{\circ} \mathrm{C}$ to destroy the pre-existing $\mathrm{A} \beta$ aggregates, followed by the removal of HFIP under vacuum freeze drying overnight. The freeze-dried protein was immediately stored in a refrigerator at $-20^{\circ} \mathrm{C}$. Before use, the lyophilized protein was dissolved in $20 \mathrm{mM} \mathrm{NaOH}$, and the solution was centrifuged at $16000 \mathrm{~g}$ for $20 \mathrm{~min}$ at $4{ }^{\circ} \mathrm{C}$ to remove the aggregates. Finally, the $\mathrm{A} \beta$ monomers were diluted with PBS to a final concentration of $25 \mu \mathrm{M}$. This solution was used immediately for the following studies of $A \beta$ aggregation and cytotoxicity.

Dot-Blot Assay. $A \beta_{42}$ monomers $(25 \mu \mathrm{M})$ were incubated with different agents at 150 rpm and $37^{\circ} \mathrm{C}$ for $48 \mathrm{~h}$. The samples $(10 \mu \mathrm{L})$ were spotted onto a nitrocellulose membrane (PALL Gelman Laboratory). After being dried at room temperature, the membrane was blocked with $10.0 \%$ skim milk in Tris-buffered saline (TBS) $(20 \mathrm{mM}$ Tris-HCl, $150 \mathrm{mM}$ $\mathrm{NaCl}, \mathrm{pH} 7.4$ ) containing $0.05 \%$ Tween 20 (TBST) on an orbital shaker for $1 \mathrm{~h}$, and washed three times $(5 \mathrm{~min})$ with TBST. The membrane was then incubated with the OC (rabbit polyclonal anti-amyloid fibril) at $1: 3000$ or the $6 \mathrm{E} 10$ (mouse monoclonal anti-A $\beta_{1-16}$ ) antibody at 1:5000 in TBST for $1 \mathrm{~h}$, washed with TBST three times (5 min), and further treated with appropriate horseradish peroxidase-labeled secondary antibodies in TBST for $1 \mathrm{~h}$. After three washes with TBST $(5 \mathrm{~min})$, the blots were developed with an ECL 
chemiluminescence kit (Beyotime, China). The density of fibril spots (OC) was analyzed with ImageJ software (NIH, USA).

Cell Viability Assays. The cytotoxicity of A $\beta$ aggregates was assessed by MTT assay on SH-SY5Y cells. A total of $5 \times 10^{3}(80 \mu \mathrm{L}) \mathrm{SH}-\mathrm{SY} 5 \mathrm{Y}$ cells/well were cultured in DMEM/F12 supplemented with 10\% FBS, $100 \mathrm{U} / \mathrm{mL}$ penicillin, and $100 \mathrm{U} / \mathrm{mL}$ streptomycin at $37^{\circ} \mathrm{C}$ under $5 \% \mathrm{CO}_{2}$ for $24 \mathrm{~h}$ in 96 -well plates. $\mathrm{A} \beta_{42}$ stock solution $(25 \mu \mathrm{M})$ was incubated without or with different concentrations of pID, LK7, LK7+pID, LK7@pID-1, LK7@pID-2, and LK7@pID-3 at $37{ }^{\circ} \mathrm{C}$ and 150 rpm for $18 \mathrm{~h}$. Then, the cells were treated with the obtained samples $(20 \mu \mathrm{L})$ and incubated for another $48 \mathrm{~h}$. Thereafter, $10 \mu \mathrm{L}$ MTT ( $5 \mathrm{mg} / \mathrm{mL}$ in PBS) was added into each well and incubated for another $4 \mathrm{~h}$. After centrifugation at $1500 \mathrm{rpm}$ for $10 \mathrm{~min}$, the supernatant was removed, and $100 \mu \mathrm{L}$ DMSO was added, followed by shaking at $150 \mathrm{rpm}$ for $10 \mathrm{~min}$ to dissolve the cells. The cell viability was calculated from the absorbance signals of formazan at $570 \mathrm{~nm}$ and estimated according to the following equation:

$$
\text { Cell Viability }(\%)=\frac{100 \% \times O D_{\text {Treated }}}{O D_{\text {Control }}}
$$

where $O D_{\text {Treated }}$ is the absorbance of the group treated with $\mathrm{A} \beta$ or/and different agents, and $O D_{\text {Control }}$ is the absorbance obtained in the group treated with PBS buffer only.

All the cell viability data are representative of at least six independent experiments and presented as mean \pm standard deviations. Analysis of variance was carried out for statistical comparisons using $t$-test, and $p<0.05$ or less was statistically significant. 
Protein Quantification Assays. Different systems $\left(A \beta_{42}\right.$ alone, $A \beta_{42}+$ pID, $A \beta_{42}+$ $25 \mu \mathrm{M}$ LK7, $\mathrm{A} \beta_{42}+25 \mu \mathrm{M}$ LK7+pID, $\mathrm{A} \beta_{42}+5 \mu \mathrm{M}$ LK7@pID-2, $\mathrm{A} \beta_{42}+12.5 \mu \mathrm{M}$ LK7@pID-2, A $\beta_{42}+25 \mu \mathrm{M}$ LK7@pID-2, A $\beta_{42}+50 \mu \mathrm{M}$ LK7@pID-2, and A $\beta_{42}+100$ $\mu \mathrm{M}$ LK7@ @ pID-2) were incubated at $37{ }^{\circ} \mathrm{C}$ with shaking at $100 \mathrm{rpm}$ for $48 \mathrm{~h}$. After centrifugation at $16000 \mathrm{~g}$ for $0.5 \mathrm{~h}$, the upper supernatant of the sample was incubated with BCA working reagent at $60{ }^{\circ} \mathrm{C}$ for $0.5 \mathrm{~h}$. Calibration was performed using different concentrations of bovine serum albumin. The volumes of different agents added to each well are listed in Table S3. The absorbance at $562 \mathrm{~nm}$ was recorded by the Tecan Infinite M200 PRO plate reader. The protein concentration of the upper supernatant was determined with the standard curve. The precipitate of samples was washed with deionized water, and then the solution was centrifuged at $16000 \mathrm{~g}$ for $30 \mathrm{~min}$. The upper supernatant was withdrawn and the precipitate of samples was dried for measuring the quality of each sample.

Stopped-Flow Fluorescent Spectroscopy. The fast kinetics of $A \beta_{42}$ interaction with pID, LK7, LK7+pID, or LK7@pID-2 was investigated by using SX20 stopped-flow fluorescent instrument (Applied Photo physics, Leatherhead, U. K.). The variation of the Rayleigh light scattering (RLS) intensity over time was measured upon excitation at 435 nm. The final concentration of $A \beta_{42}$ was $25 \mu \mathrm{M}$, and the concentration of pID, LK7, LK7+pID, or LK7@pID-2 ranged from 5 to $100 \mu \mathrm{M}$. Data were collected and analyzed using the Pro-Data software. 
Table S1. Properties of LK7@pID conjugates

\begin{tabular}{cccccc}
\hline LK7@pID & DS $^{\mathrm{a}}$ & $\begin{array}{c}\text { Size }^{\mathrm{b}} \\
(\mathrm{nm})\end{array}$ & $\begin{array}{c}\text { PDI }^{\mathrm{b}} \\
(-)\end{array}$ & $\begin{array}{c}\zeta \text {-potential }^{\mathrm{b}} \\
(\mathrm{mV})\end{array}$ & $\begin{array}{c}\text { CAC } \\
(\mathrm{mol} / \mathrm{L})\end{array}$ \\
\hline$\square$ & 4.2 & $198.4 \pm 22.5$ & $0.578 \pm 0.034$ & $-7.52 \pm 2.56$ & $6.74 \times 10^{-8}$ \\
$\square$ & 8.4 & $113 \pm 17.2$ & $0.473 \pm 0.031$ & $-15.42 \pm 5.36$ & $1.17 \times 10^{-9}$ \\
$\square$ & 10.8 & $93.1 \pm 13.3$ & $0.394 \pm 0.011$ & $-22.45 \pm 4.55$ & $7.12 \times 10^{-9}$ \\
\hline
\end{tabular}

${ }^{a}$ Degrees of substitution (DS) was defined as the number of conjugated LK7 molecules per one hundred monomer repeating units in pID.

${ }^{b}$ Determined with DLS in $100 \mathrm{mM}$ phosphate buffer solution containing $10 \mathrm{mM}$ sodium chloride (PBS) (pH7.4). 
Table S2. The quality of precipitate and protein concentration of upper supernatant after the incubation of $\mathrm{A} \beta_{42}(25 \mu \mathrm{M})$ without or with different agents

\begin{tabular}{lcc}
\hline Sample $^{\mathrm{a}}$ & $\begin{array}{c}\text { Precipitate } \\
(\mathrm{mg})\end{array}$ & $\begin{array}{c}\text { Protein in supernatant } \\
(\mu \mathrm{g} / \mathrm{mL})\end{array}$ \\
\hline $\mathrm{A} \beta_{42}$ & $0.16 \pm 0.03$ & $23.2 \pm 0.2$ \\
$\mathrm{~A} \beta_{42}+0.97 \mathrm{mg} / \mathrm{mL} \mathrm{pID}$ & $0.15 \pm 0.01$ & $22.4 \pm 0.3$ \\
$\mathrm{~A} \beta_{42}+25 \mu \mathrm{M}$ LK7 & $0.17 \pm 0.03$ & $26.3 \pm 0.2$ \\
$\mathrm{~A} \beta_{42}+25 \mu \mathrm{M}$ LK7 $+0.97 \mathrm{mg} / \mathrm{mL} \mathrm{pID}$ & $0.18 \pm 0.01$ & $25.7 \pm 0.2$ \\
$\mathrm{~A} \beta_{42}+5 \mu \mathrm{M}$ LK7@pID-2 & $0.18 \pm 0.01$ & $22.1 \pm 0.4$ \\
$\mathrm{~A} \beta_{42}+12.5 \mu \mathrm{M}$ LK7@pID-2 & $0.22 \pm 0.04$ & $19.7 \pm 0.1$ \\
$\mathrm{~A} \beta_{42}+25 \mu \mathrm{M}$ LK7@ $\mathrm{pID}-2$ & $0.25 \pm 0.03$ & $16.3 \pm 0.1$ \\
$\mathrm{~A} \beta_{42}+50 \mu \mathrm{M}$ LK7@pID-2 & $0.35 \pm 0.11$ & $13.9 \pm 0.2$ \\
$\mathrm{~A} \beta_{42}+100 \mu \mathrm{M}$ LK7@pID-2 & $0.49 \pm 0.07$ & $10.1 \pm 0.1$ \\
\hline
\end{tabular}

a The experimental volume was $2 \mathrm{~mL}$; protein $\left(\mathrm{A} \beta_{42}\right)$ concentration was $25 \mu \mathrm{M}(112.8$ $\mu \mathrm{g} / \mathrm{mL})$. The concentration of LK7@pID-2 was expressed by that of LK7 equivalent. 
Table S3. Volumes of different solutions added in different wells in the BCA assay ${ }^{\text {a }}$

\begin{tabular}{|c|c|c|c|c|}
\hline & & $\begin{array}{c}\text { BSA or Sample } \\
(\mu \mathrm{L})\end{array}$ & $\begin{array}{c}\mathrm{ddH}_{2} \mathrm{O} \\
(\mu \mathrm{L})\end{array}$ & $\begin{array}{c}\text { Working reagent } \\
\qquad(\mu \mathrm{L})\end{array}$ \\
\hline \multirow{7}{*}{ BSA } & 1 & 0 & 10 & 200 \\
\hline & 2 & 1 & 9 & 200 \\
\hline & 3 & 2 & 8 & 200 \\
\hline & 4 & 4 & 6 & 200 \\
\hline & 5 & 6 & 4 & 200 \\
\hline & 6 & 8 & 2 & 200 \\
\hline & 7 & 10 & 0 & 200 \\
\hline $\mathrm{S} 1$ & & 25 & 0 & 200 \\
\hline $\mathrm{S} 2$ & & 25 & 0 & 200 \\
\hline $\mathrm{S} 3$ & & 25 & 0 & 200 \\
\hline S4 & & 25 & 0 & 200 \\
\hline S5 & & 25 & 0 & 200 \\
\hline S6 & & 25 & 0 & 200 \\
\hline S7 & & 25 & 0 & 200 \\
\hline S8 & & 25 & 0 & 200 \\
\hline S9 & & 25 & 0 & 200 \\
\hline S10 & & 25 & 0 & 200 \\
\hline
\end{tabular}

${ }^{a} \mathrm{~S} 1, \mathrm{~A} \beta_{42}$ monomer solution; $\mathrm{S} 2$, upper supernatant of $\mathrm{A} \beta_{42}$ after incubation for $48 \mathrm{~h}$; $\mathrm{S} 3$, upper supernatant of $A \beta_{42}+$ pID after incubation for $48 \mathrm{~h}$; S4, upper supernatant of $A \beta_{42}$ $+25 \mu \mathrm{M}$ LK7 after incubation for $48 \mathrm{~h}$; S5, upper supernatant of $\mathrm{A} \beta_{42}+25 \mu \mathrm{M}$ LK7+pID after incubation for $48 \mathrm{~h}$; S6, upper supernatant of $\mathrm{A} \beta_{42}+5 \mu \mathrm{M}$ LK7@pID-2 after incubation for $48 \mathrm{~h}$; S7, upper supernatant of $\mathrm{A} \beta_{42}+12.5 \mu \mathrm{M}$ LK7@pID-2 after incubation for $48 \mathrm{~h}$; S8, upper supernatant of $\mathrm{A} \beta_{42}+25 \mu \mathrm{M}$ LK7@pID-2 after incubation for $48 \mathrm{~h}$; S9, upper supernatant of $\mathrm{A} \beta_{42}+50 \mu \mathrm{M}$ LK7@pID-2 after incubation for $48 \mathrm{~h}$; S10, upper supernatant of $A \beta_{42}+100 \mu \mathrm{M}$ LK7@pID-2 after incubation for $48 \mathrm{~h}$. 


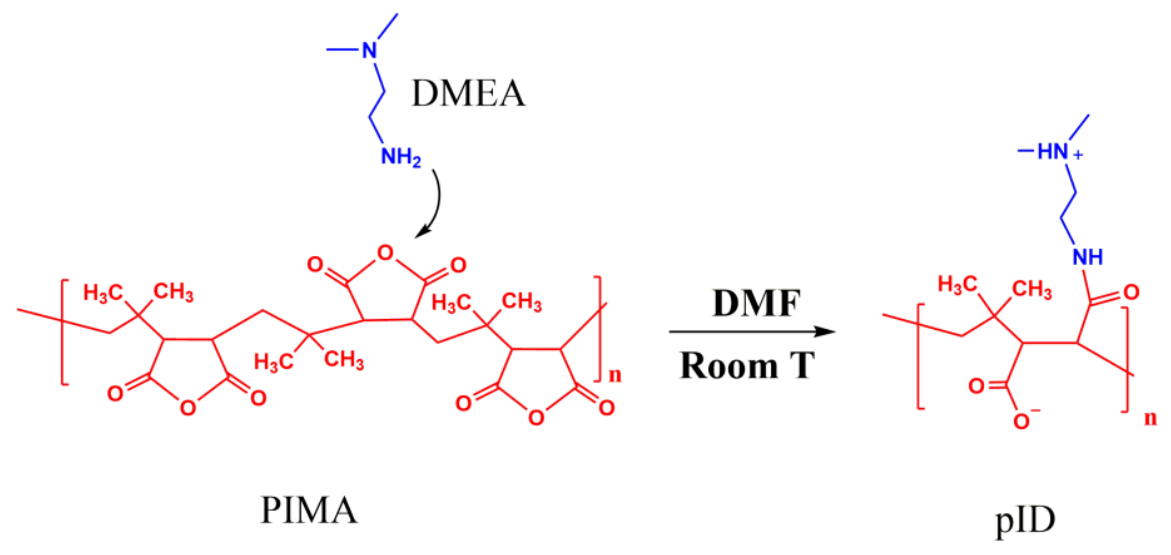

Figure S1. Synthesis of pID. 


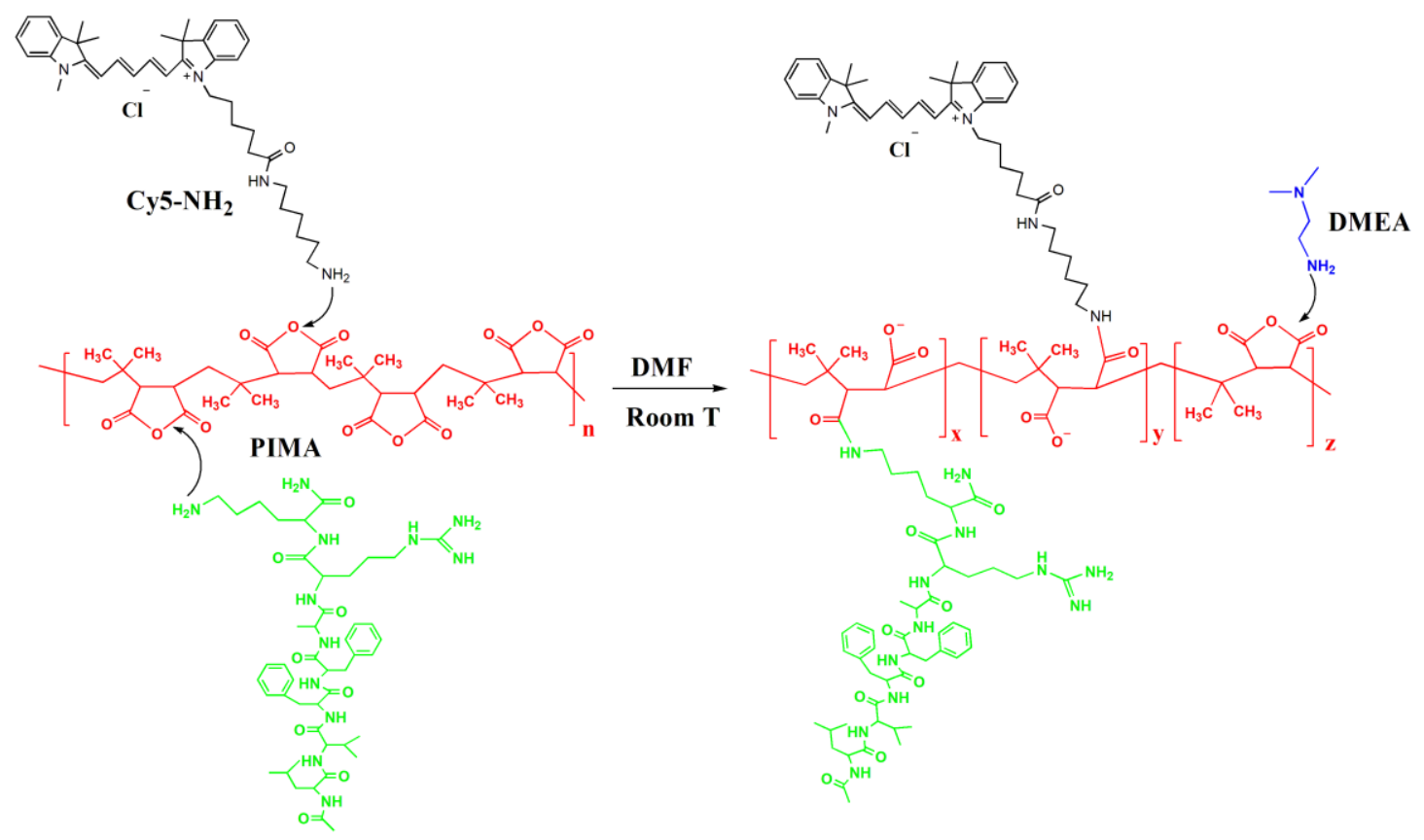

Ac-LVFFARK-NH (LK7) $^{2}$

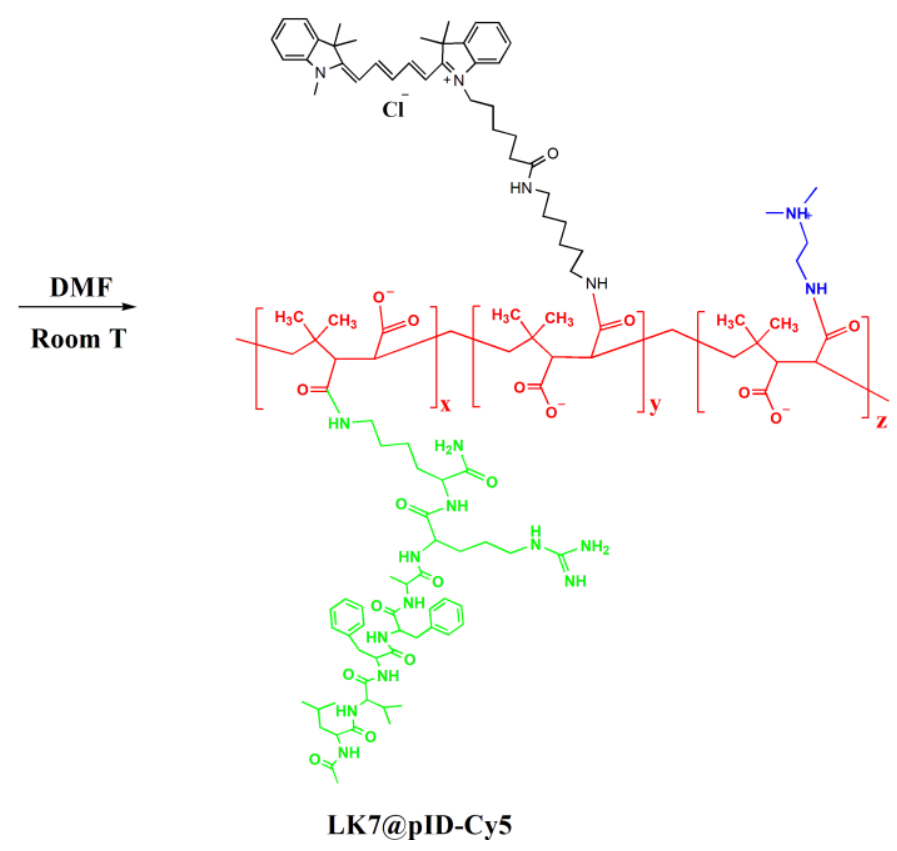

Figure S2. Synthesis of LK7@pID-Cy5. 


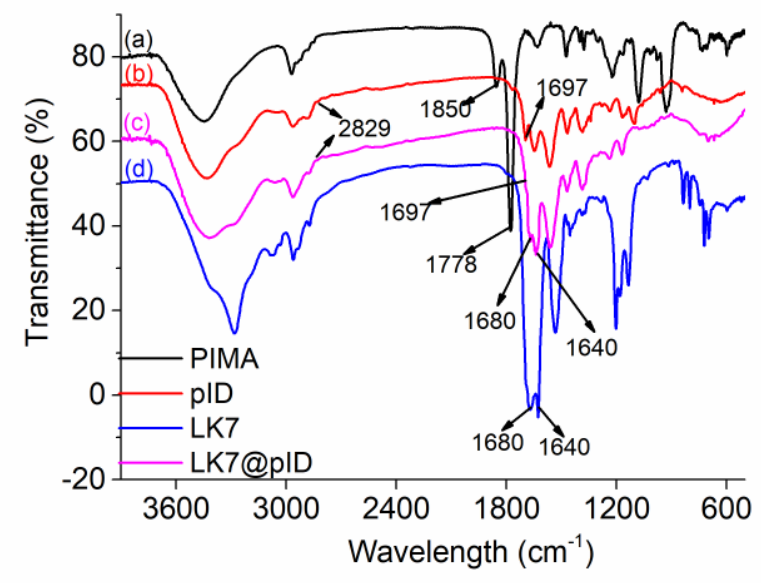

Figure S3. FT-IR spectra of (a) PIMA, (b) pID, (c) LK7@pID, and (d) LK7.

The peaks at $1850 \mathrm{~cm}^{-1}$ and $1778 \mathrm{~cm}^{-1}$ in (a) correspond to the anhydride rings of PIMA, and these peaks disappear in (b) and (c), implying that the anhydride rings had reacted with DMEA. For pID, the adsorption peaks at $2829 \mathrm{~cm}^{-1}$ in (b) is the asymmetric stretching vibrations of - $\mathrm{CH}$ of the methyl group linked to the nitrogen atom of DMEA, and the peak at $1697 \mathrm{~cm}^{-1}$ in (b) and (c) represents $-\mathrm{C}=\mathrm{O}$ stretching of the carboxylic acid groups formed after the hydrolysis of anhydride. The peak at $1640 \mathrm{~cm}^{-1}$ in (c) and (d) represents the vibrations of $-\mathrm{C}=\mathrm{N}$ of arginine of $\mathrm{LK} 7$. 

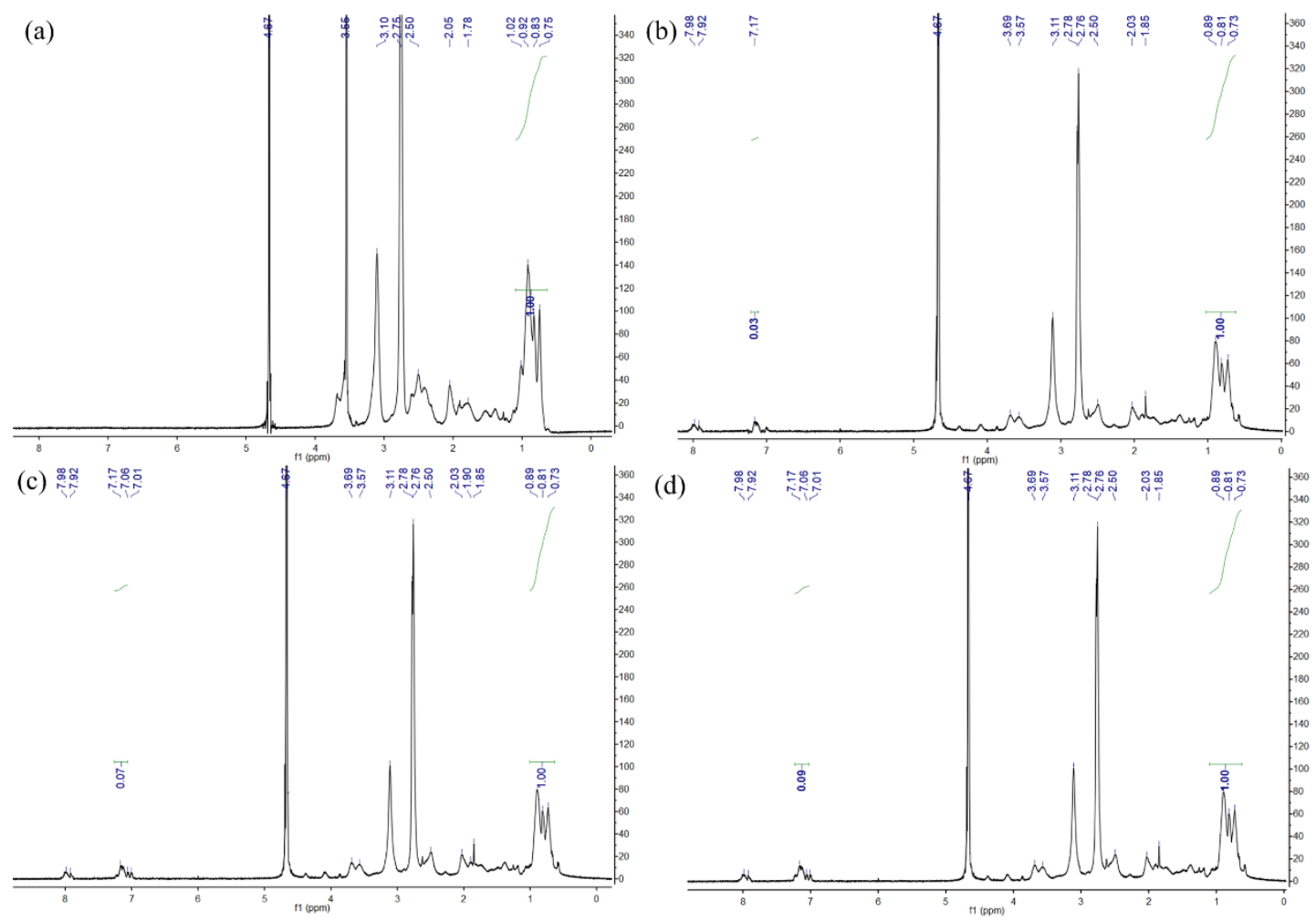

Figure S4. ${ }^{1} \mathrm{H}$ NMR spectra of (a) pID, (b) LK7@pID-1, (c) LK7@pID-2, and (d) LK7@pID-3 in D2O.

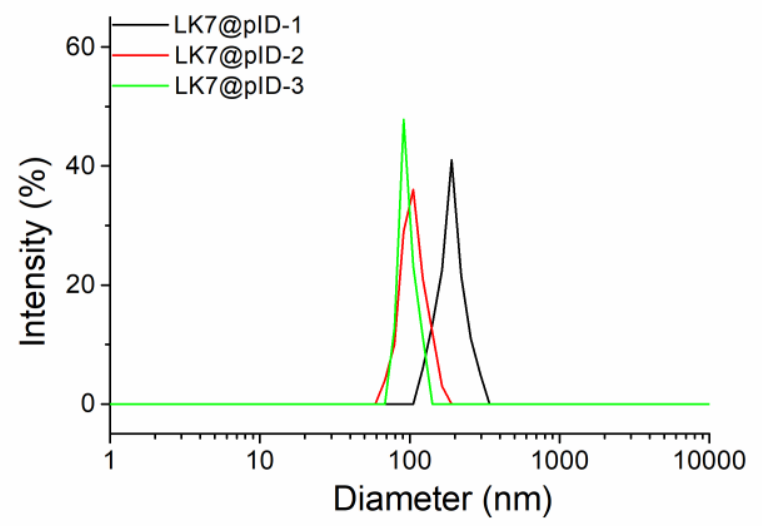

Figure S5. Sizes of the micelles of three LK7@pID conjugates in PBS. 

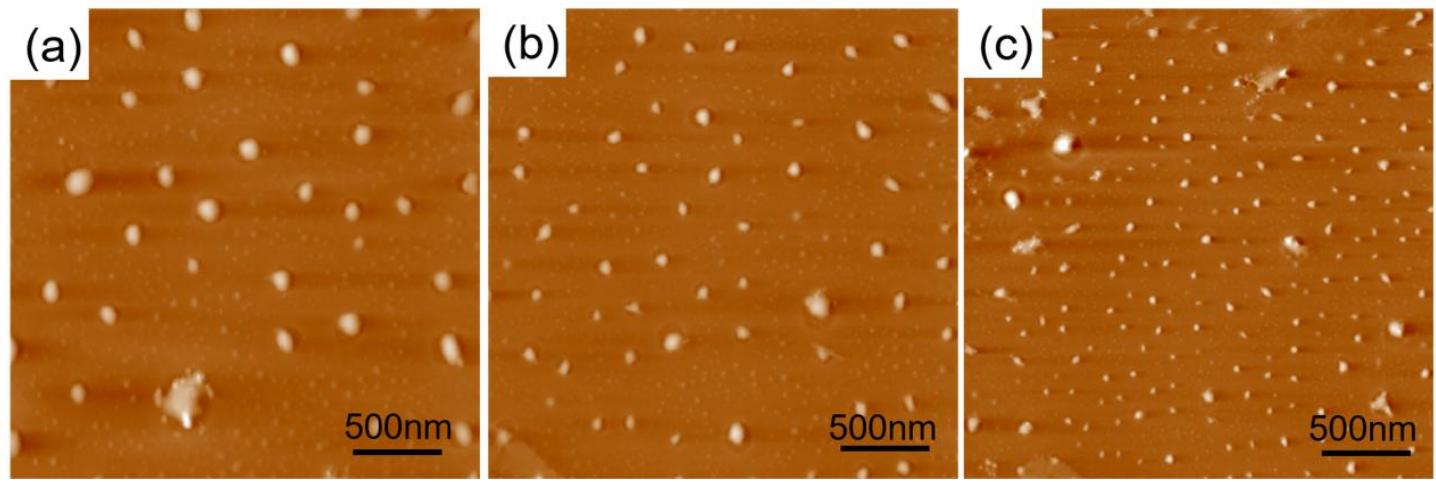

Figure S6. AFM images of (a) LK7@pID-1, (b) LK7@pID-2, and (c) LK7@pID-3 micelles in PBS.

(a)

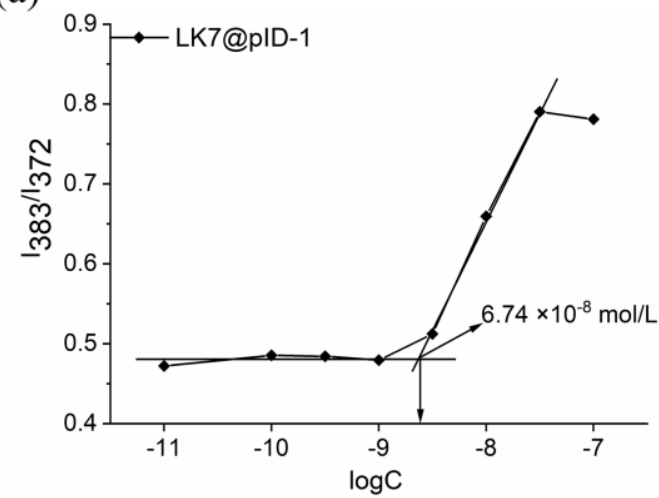

(c)

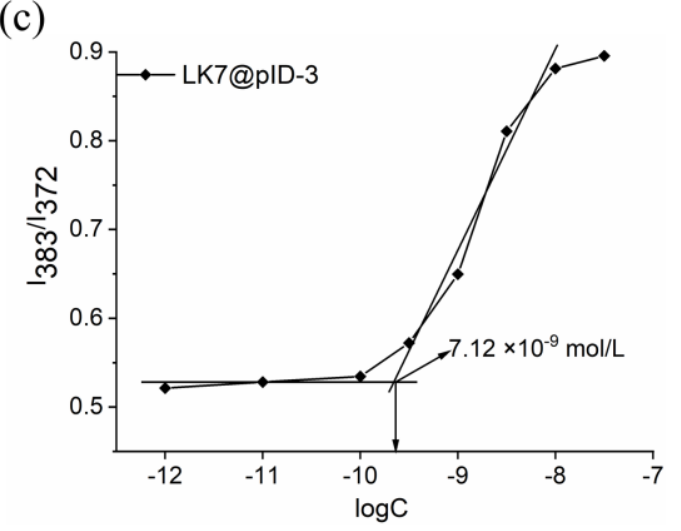

(b)

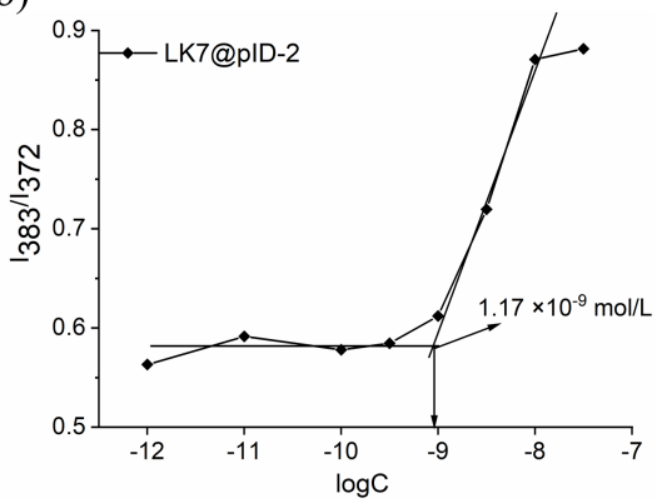

Figure S7. Plots for determination of the CAC values of (a) LK7@pID-1, (b) LK7@pID-2, and (c) LK7@pID-3 micelles in PBS. 


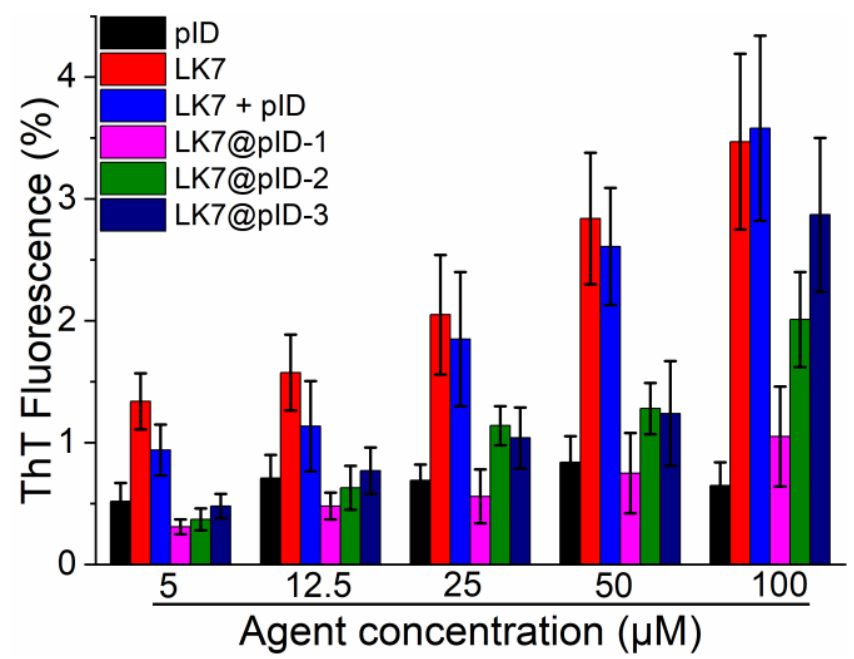

Figure S8. Self-aggregation of pID, LK7, LK7+pID, LK7@pID-1, LK7@pID-2, and LK7@pID-3 measured by ThT fluorescence. The fluorescence of A $\beta_{42}$ after incubation for $48 \mathrm{~h}$ was set to $100 \%$. The concentration of LK7@pID was expressed by that of LK7 equivalent. The concentration of (LK7+pID) group was represented by LK7 concentration while the pID concentration was the same as that in LK7@pID-2 at the equivalent LK7 concentration.
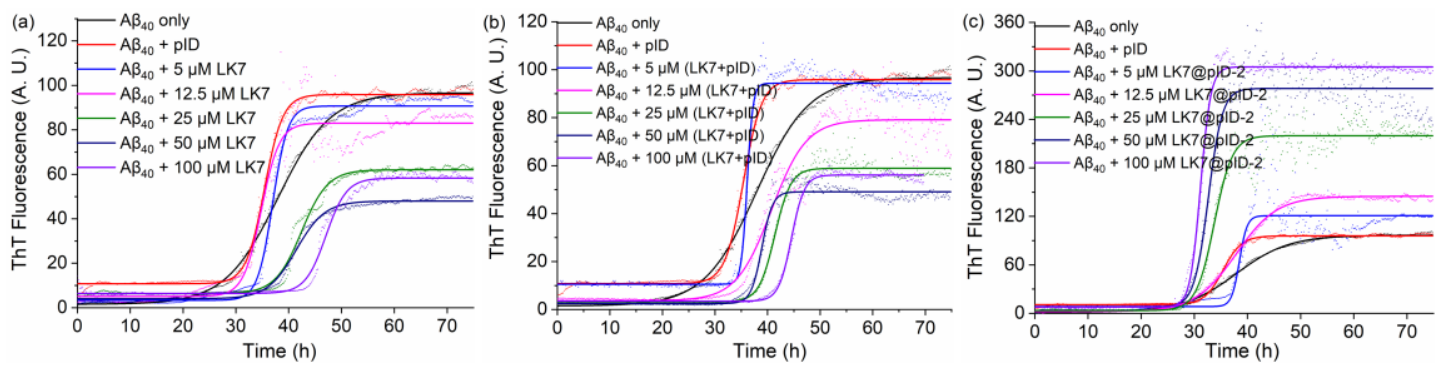

Figure S9. Aggregation kinetics of $A \beta_{40}$ incubated without or with (a) LK7, (b) LK7+pID, and (c) LK7@pID-2 at different concentrations. A $\beta_{40}$ concentration was $25 \mu \mathrm{M}$. The concentration of LK7@pID-2 was expressed by that of LK7 equivalent. The pID concentration in (b) was the same as that in LK7@pID-2 at the equivalent LK7 concentration. 
(a)

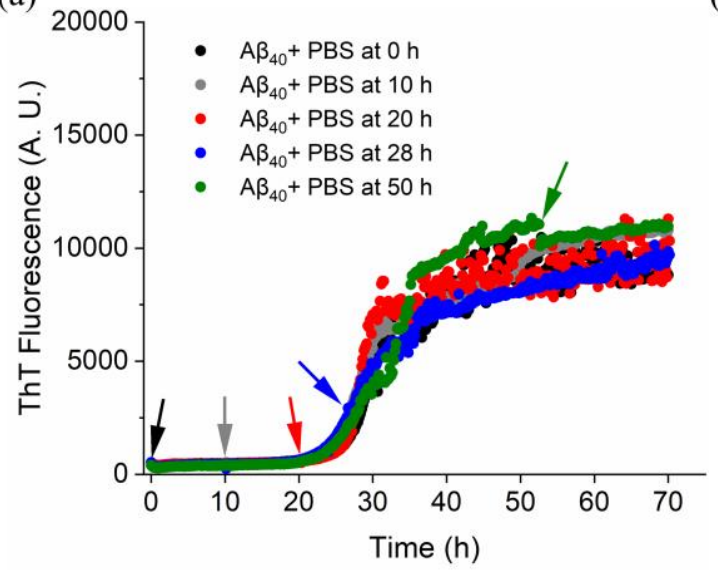

(b)

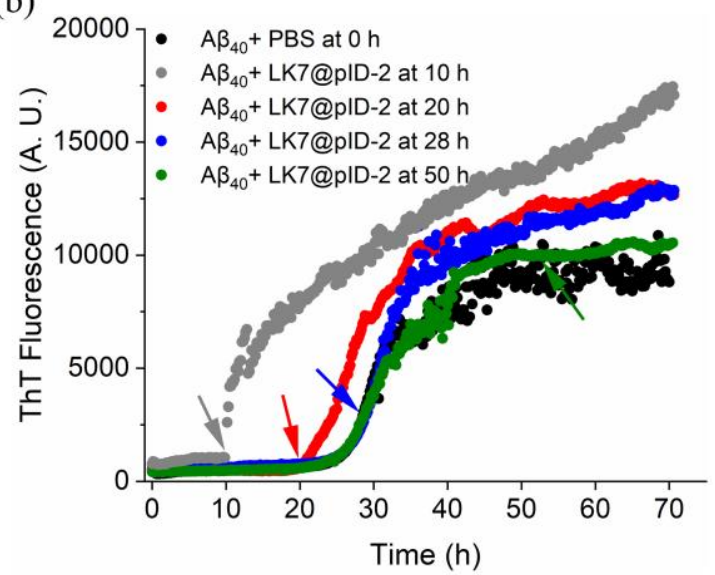

Figure S10. Aggregation kinetics of A $\beta_{40}$ when (a) PBS or (b) LK7@pID-2 was added at different time points indicated by the arrows. The final concentration of $A \beta_{40}$ and LK7@pID-2 were both $25 \mu \mathrm{M}$. 


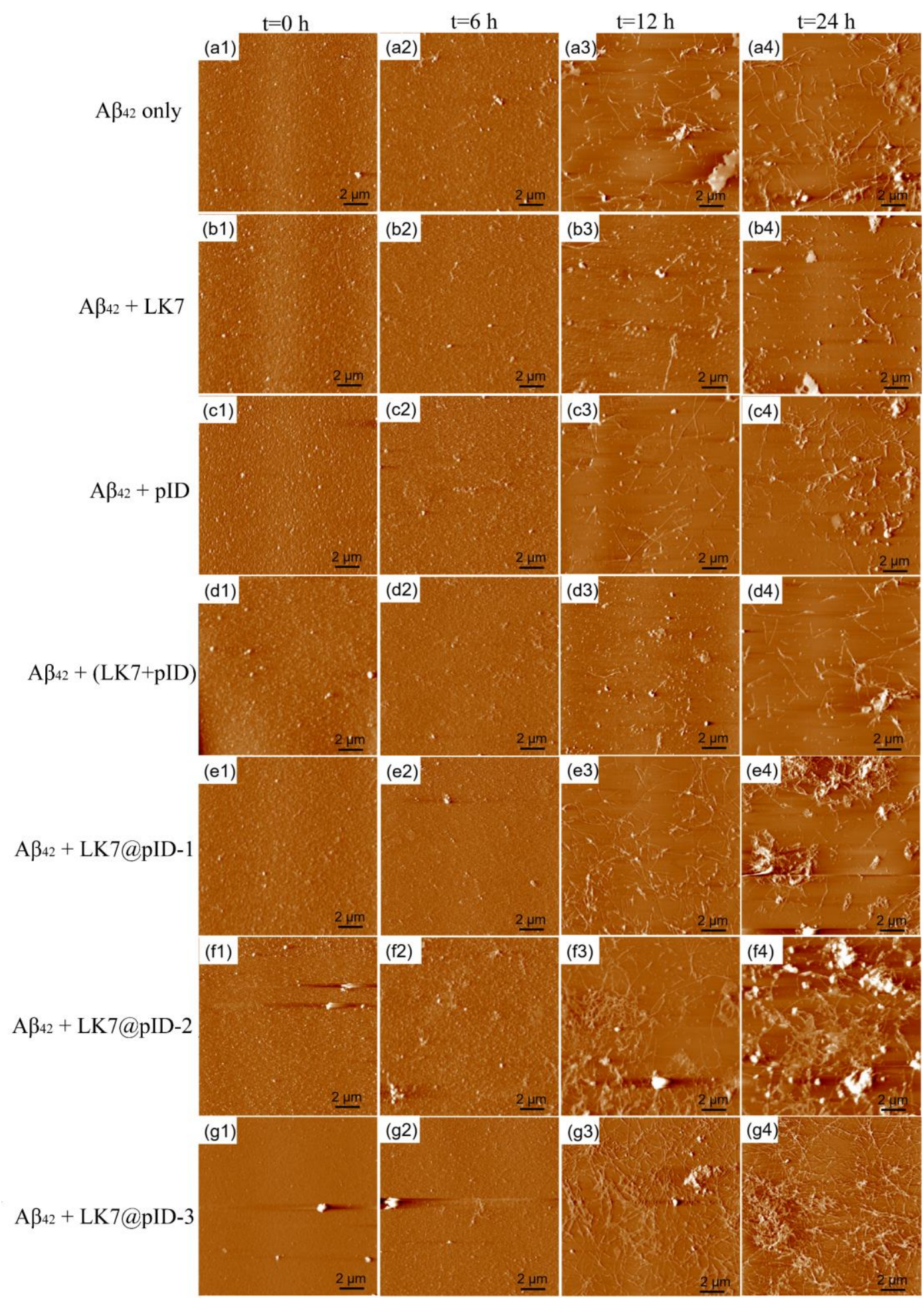

Figure S11. AFM images of (a) $A \beta_{42}$ alone and $A \beta_{42}$ incubated with (b) LK7, (c) pID, (d) LK7 + pID, (e) LK7@pID-1, (f) LK7@pID-2, or (g) LK7@pID-3. The observations were conducted at different time intervals $(0,6,12,24 \mathrm{~h})$ indicated above the images. 

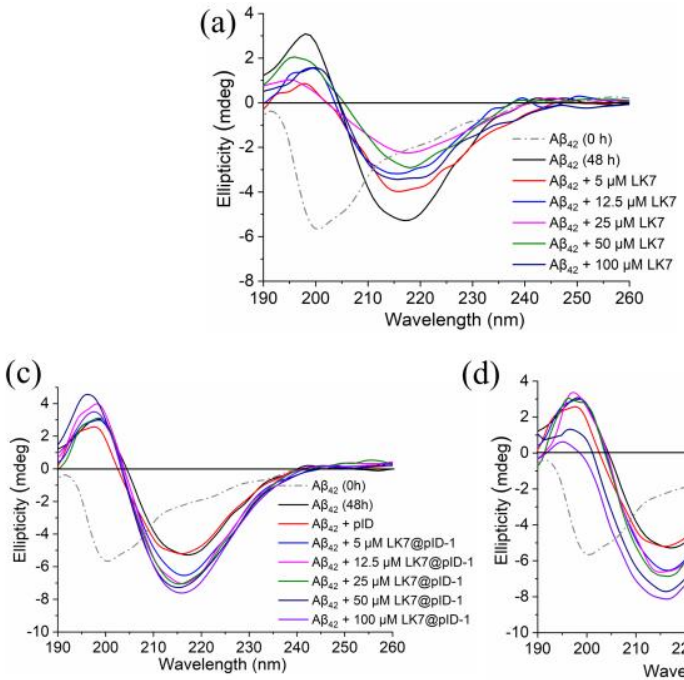

(d)
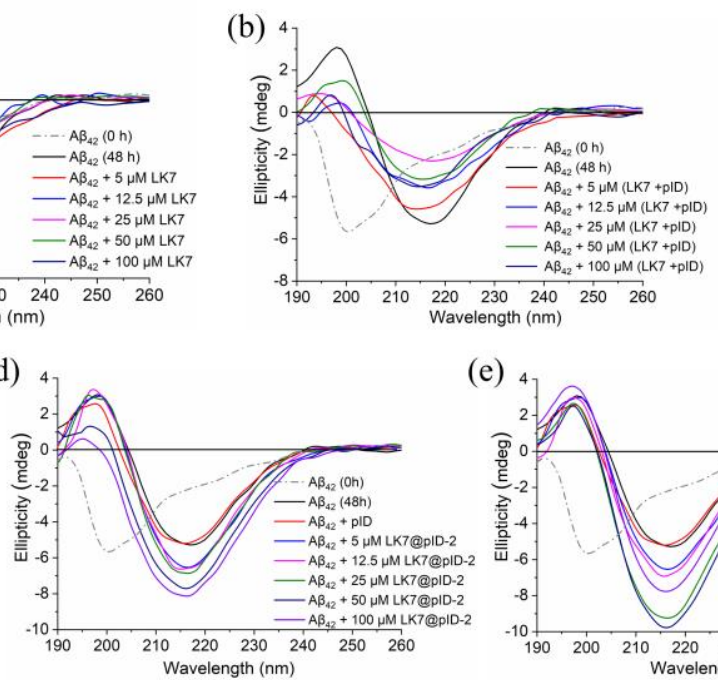

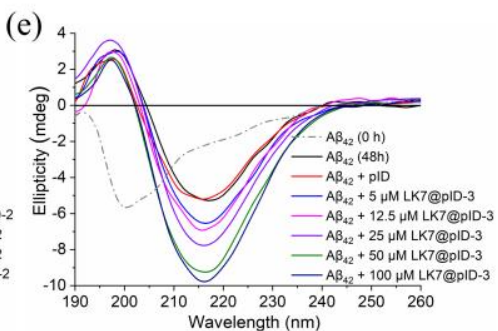

Figure S12. The far-UV circular dichroism spectra of $A \beta_{42}$ incubated without or with various agents of different concentrations. (a) A $\beta_{42}$ with LK7, (b) A $\beta_{42}$ with LK7+pID, (c) A $\beta_{42}$ withLK7@pID-1, (d) A $\beta_{42}$ withLK7@pID-2, and (e) A $\beta_{42}$ withLK7@pID-3. The concentration of LK7@pID conjugates was expressed by that of LK7 equivalent. The concentration of $(\mathrm{LK} 7+\mathrm{pID})$ group was represented by LK7 concentration while the pID concentration was the same as that in LK7@pID-2 at the equivalent LK7 concentration. 

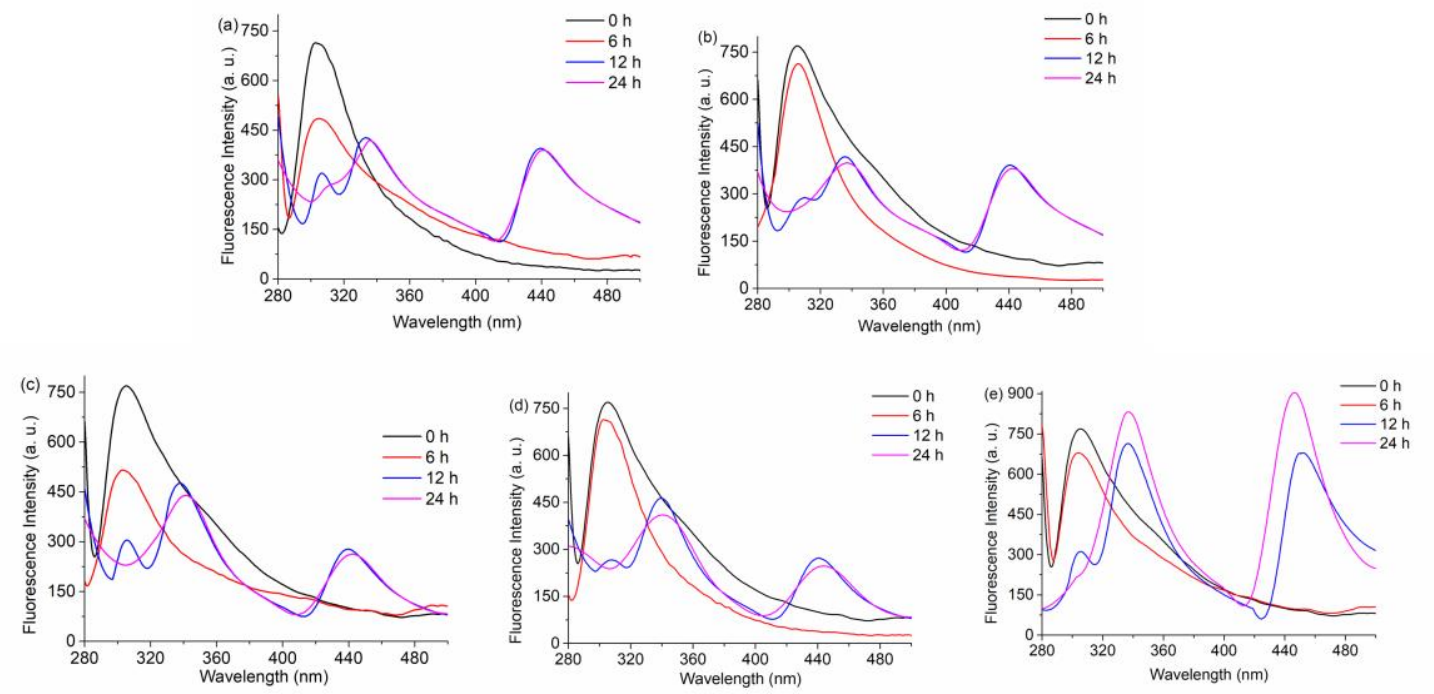

Figure S13. Time course of fluorescence emission spectra of (a) $A \beta_{42}$ only, (b) $A \beta_{42}+$ pID, (c) $A \beta_{42}+$ LK7, (d) $A \beta_{42}+$ LK7+pID, and (e) $A \beta_{42}+$ LK7@pID-2 during the 24-h incubation at $37^{\circ} \mathrm{C}$. $\mathrm{A} \beta_{42}$ concentration was $25 \mu \mathrm{M}$. 
(a)

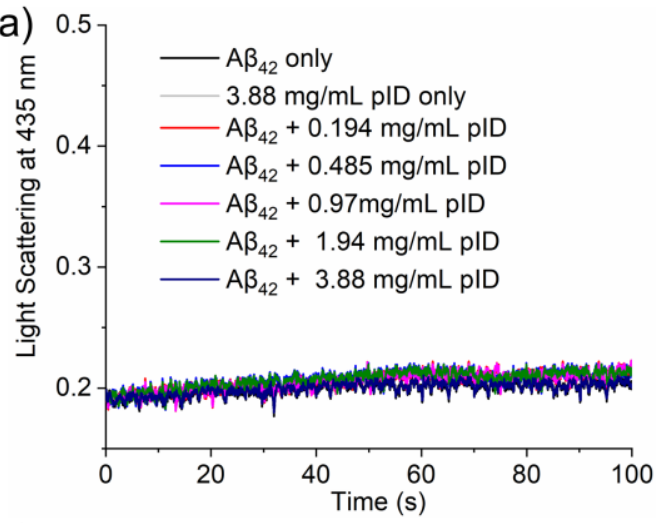

(c)

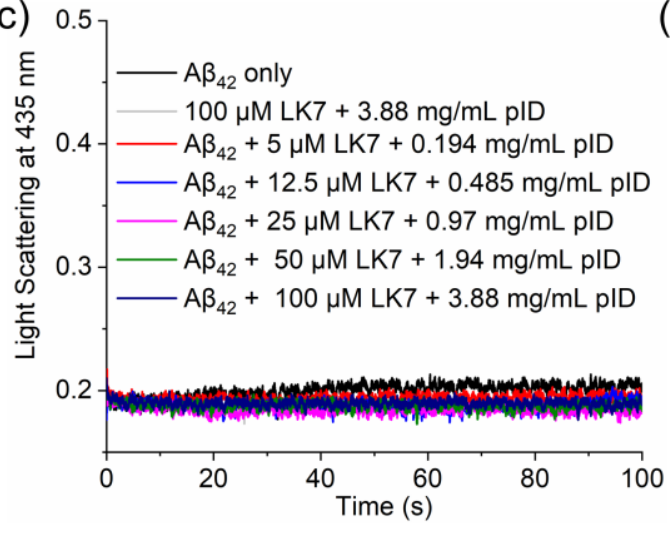

(b)

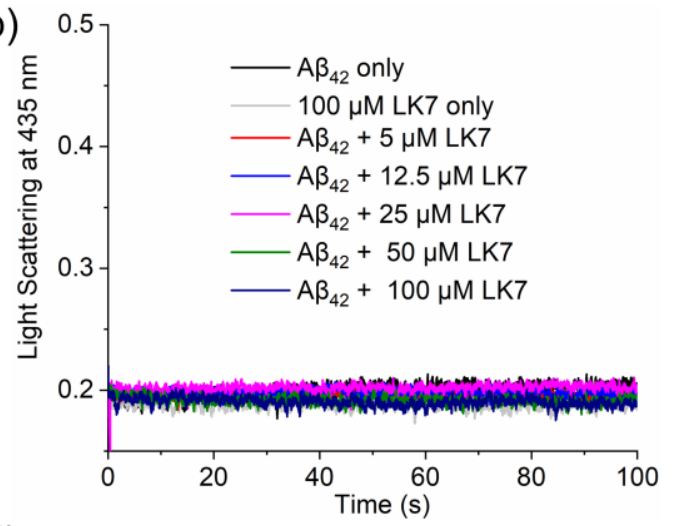

(d)

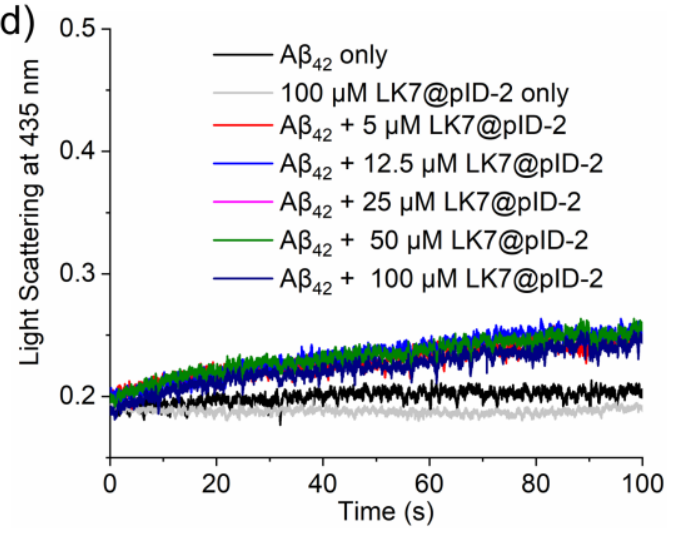

Figure S14. Kinetic traces followed by stopped-flow fluorescence of (a) $A \beta_{42}$ monomer + pID, (b) $\mathrm{A} \beta_{42}$ monomer + LK7, (c) $\mathrm{A} \beta_{42}$ monomer $+(\mathrm{LK} 7+\mathrm{pID})$, and (d) $\mathrm{A} \beta_{42}$ monomer + LK7@pID-2. A $\beta_{42}$ concentration was $25 \mu \mathrm{M}$. The concentration of LK7@pID-2 was represented by that of LK7 equivalent. 


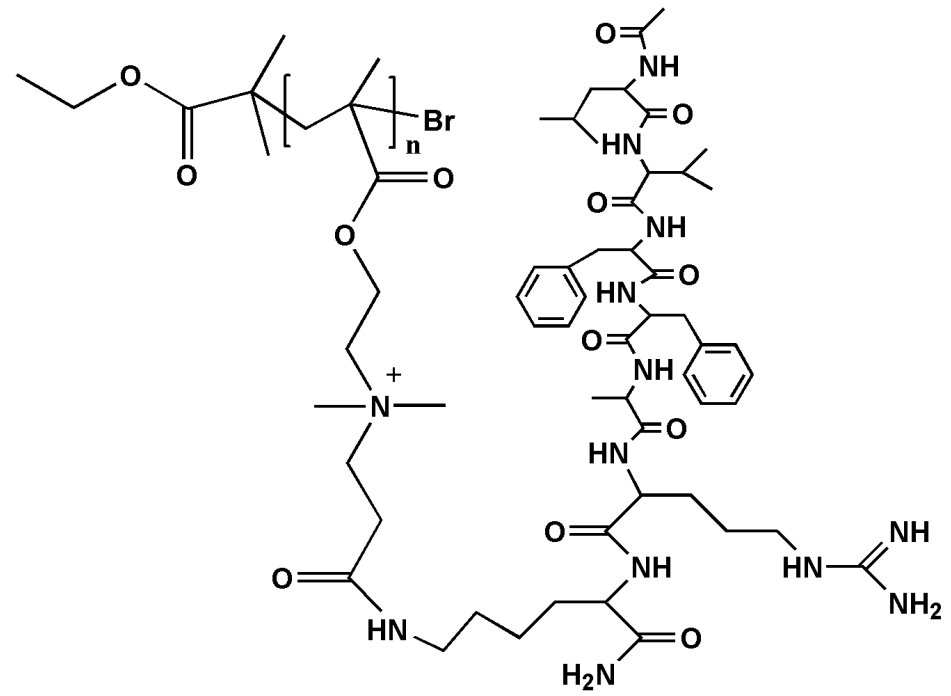

Figure S15. Structure of LK7@pCB conjugates. 